\title{
Optimum Process Parameters Selection for Brinell Hardness Number of Natural Fiber Reinforced Composites Using Taguchi Method
}

\author{
Sk. Suzauddin Yusuf ${ }^{1,3}$, Md. Nurul Islam², Md. Hasan Ali $^{3}$, Md. Washim Akram ${ }^{3 *}$, Md. Abubakar Siddique
}

\author{
${ }^{1}$ M.Sc. Student, Department of Mechanical Engineering, Rajshahi University of Engineering and Technology, Rajshahi-6204, Bangladesh \\ ${ }^{2}$ Department of Mechanical Engineering, Rajshahi University of Engineering and Technology, Rajshahi-6204, Bangladesh \\ ${ }^{3}$ Faculty of Mechanical and Production Engineering, Bangladesh Army University of Science and Technology, Saidpur-5310, Bangladesh
}

\begin{abstract}
DOI: $10.36348 /$ SJEAT.2019.v04i10.005
| Received: 07.10.2019 | Accepted: 14.10.2019| Published: 27.10.2019

*Corresponding author: Md. Washim Akram
\end{abstract}

\section{Abstract}

Now-a-days, natural fiber-reinforced polymer matrix composites have received large attention of the researchers in various applications. The properties of natural fiber composites to a large extent influenced by the type of fibers, treatment method, types of hardener and resin, and fabrication method. In the present study, the hardness behavior of sponge gourd, coir, and jute fiber reinforced thermosetting resin-based composite has been investigated experimentally. Natural fibers were treated with $5 \% \mathrm{NaOH}$ solution by volume and hand lay-up technique was used to fabricate these composites. The $\mathrm{Wt} \%$ (weight percentage) ratio of resin and hardener, $\mathrm{Wt} \%$ of resin \& hardener in composite, $\mathrm{Wt} \%$ ratio of sponge gourd \& jute, and $\mathrm{Wt} \%$ ratio of sponge gourd \& coir are considered as control factors which were optimized using Taguchi L9 orthogonal design of experiments. The optimal control factor combination for maximum Brinell hardness was found out and the predicted optimal value, obtained from Taguchi analysis, of Brinell hardness was confirmed by validation experiments. At last, the interactions between control factors or input parameters with Brinell hardness are revealed graphically by interaction plots.

Keywords: Natural composites, hand lay-up technique, Brinell hardness, Taguchi L9 orthogonal design of experiments, interaction plot.

Copyright @ 2019: This is an open-access article distributed under the terms of the Creative Commons Attribution license which permits unrestricted use, distribution, and reproduction in any medium for non-commercial use (NonCommercial, or CC-BY-NC) provided the original author and source are credited.

\section{INTRODUCTION}

Natural fiber polymer composites are a composite material consisting of a polymer matrix embedded with high-strength natural fibers, like jute, oil palm, sisal, kenaf and flax. [1]. Natural fiber composites (NFC) can be a combination of either natural fibers/synthetic resin or natural fibers/bio-resin. Bio-resin means bio-degradable resin. Both synthetic and bio-resin can be either in the form of thermoset or thermoplastic type of resin. Natural fibers/thermoplastic composites have been used in automotive applications [2]. However, most composites for infrastructure are made out of thermoset resins [3]. NFC has been used also in biomedical applications for bone and tissues repair and reconstruction [4]. Fiber-reinforced composites got considerable attention in numerous applications because of the good properties and superior advantages of natural fiber over synthetic [5]. NFC are obtaining more attention in recent years in various application including automotive, merchandise, structural and infrastructure. However, with their unique and wide range of variability, natural fiber composites could emerge as a new alternative engineering material which can substitute the use of synthetic fiber composites [6].

Sponge gourds, the fruit of Luffa cylindrica, are widely used throughout the world. The fruit, approximately $30 \mathrm{~cm}$ (12 in) long, resembles a cucumber in shape and size. Now a days, Sponge gourd fibers are used in different natural or hybrid composites fabrication [12-17]. Coir is a fruit fiber. It comes from the husk of the coconut fruit. Brown coir is obtained from mature coconuts and has higher contents of lignin [18]. Coir is an abundant, versatile, renewable, cheap, and biodegradable lignocelluloses fiber used for making a wide variety of products. Coir has also been tested as filler or reinforcement in different composite materials. In this work, brown coir fibers were used. Coir fiber reinforced polymer composites have found application in furniture, packaging, as filler in different composite materials [19]. Jute is a naturally available fiber. It is also easy to grow and have the potential to be a cash crop for local farmers. Different composites have been fabricated by using jute fibers. Jute fiber is $100 \%$ bio- 
degradable and recyclable and thus environmental friendly. Two types of jutes are cultivated in Bangladesh. They are white jute (Corchorus capsularis) and tossa jute (Corchorus olitorius) [20]. White jute is used in this research. The term epoxy has been widely adapted for many uses beyond fiber reinforced polymer composites which are used as the resin matrix to efficiently hold the fiber in place. The epoxy resin and hardener may be mixed and stored for some time while using latent hardener prior to use. In this research, epoxy resin (Araldite AW 106/ADR 246 TX) was used as the matrix material. Hardener (Hardener HV 953 IN /ADH 160 and Methyl Ethyl Peroxide) [21], was used to provide more strength and improve the interfacial adhesion to the composites.

Physical, mechanical, and flammability properties of coconut fiber reinforced polypropylene composite panels were evaluated. The flexural strength, tensile strength, and hardness of the composites improved with increasing the coir fiber content up to 60 Wt\% [7]. Vineet Kumar Bhaga et al. tested the physical and mechanical performance of luffa-coir fiberreinforced epoxy resin based hybrid composites. The maximum hardness value of $30.55 \mathrm{H}_{\mathrm{v}}$ is obtained for the same conditions [8]. Short jute fiber $(2-3 \mathrm{~mm})$ reinforced polypropylene based composites (20\% fiber by weight) were fabricated using compression molding and the mechanical properties were evaluated. Hardness of the composites were found to be 96 shore-A [9]. Physico-mechanical properties of jute-coir fiber reinforced hybrid polypropylene composites were tested by Salma Siddika et al. Composites were manufactured by using hot press machine at four levels of fiber loading $(5,10,15$ and $20 \mathrm{Wt} \%)$. Jute and coir fibers were utilized at a ratio of (1:1) during composite manufacturing. Average hardness values increased with an increase in fiber loading [10]. Sailesh and Shanjeevi [11] predicted the optimal process parameter setting for maximum hardness value of the bamboo/banana/glass fiber reinforced hybrid composites using Taguchi method.

As far as the author concern, there is no natural composite had been made yet by using sponge gourd, coir and jute. Taguchi method, being a simple, efficient and systematic approach to optimize designs for performance, quality and cost, is used in many engineering applications. The objectives of this research work are to fabricate epoxy resin based sponge gourd, coir and jute fiber reinforced natural composites. Besides, the investigation of hardness of these composites with different compositions have been performed. To understand the effect of different parameters on output characteristics and find out the optimum experimental condition of this composites by utilizing the Taguchi method is another important objective this research. Confirmation test was performed to verify the predicted value of Brinell hardness with experimental value. The interactions between different control factors on hardness of the composite also investigated by interaction plot results.

\section{MATERIALS AND METHODS Materials}

In this work, natural fibers (sponge gourd, coir, and jute) were used for reinforcement in the composite. Sponge gourd, coir, and jute are available in Bangladesh. Caustic Soda $(\mathrm{NaOH})$ is used for treatment of natural fibers. Thermoset polymers are used as a matrix material for most of the composite materials. Epoxy resins, one of the thermosetting resin, have excellent mechanical and chemical properties and corrosion resistance. The epoxy resin (Araldite AW 106) was used as the matrix material. Hardener (Hardener HV 953 IN) were used to provide more strength and improve the interfacial adhesion to the composites.

\section{Composite Fabrication}

The fabrication processes typically involve some form of molding, to shape the resin-hardener mixer and reinforcement. Available composite fabrication techniques for industries purposes are compression molding, vacuum molding, and resin transfer molding. The hand lay-up process of manufacturing is one of the simplest and easiest methods for manufacturing composites. In this study, the composites were manufactured by the hand lay-up process. The primary significance of the hand lay-up technique is to fabricate very large, complex parts with reduced manufacturing times. Additional benefits are simple equipment and tooling that are relatively less expensive than other manufacturing processes. The complete sequential fabrication process is shown in figure 1 .

At first, the mold, made of mild steel plate, was cleaned. Then, the dimension of the mold was $275 \times 155 \times 5 \mathrm{~mm}^{3}$. Parachute cloth was applied to the mold surface for easy removal of composite. The mass of resin, hardener, and chemically treated fibers were measured. The resin was mixed with the hardener properly at certain proportion according to the composition of different samples. For example; in sample 7, the proportion of epoxy resin and hardener was $1: 1$ and $\mathrm{Wt} \%$ of resin \& hardener in composite was $91 \%$. The fibers were mixed properly at appropriate proportion with the epoxy and hardener mixer. For example; in sample $7, \mathrm{Wt} \%$ of fibers in composites were $9 \%$ and $\mathrm{Wt} \%$ ratio of Sponge gourd, Jute, and Coir fibers were 3:1:3 (Sponge gourd $=42.857 \%$, Jute $=14.286 \%$, and Coir $=42.857 \%$ ). After mixing, the mixer of epoxy resin with natural fibers was then poured into the mold. Brushes and hand rollers were used to remove any void in the fiber structure and to spread the resin evenly throughout the fibers. Finally, a load is applied over the mold to remove any excess air present at air gap in between the fibers and resin, and then kept for 24 hours to get the perfect samples. After 
the composite material get hardened completely, the composite material is taken out from the mold and rough edges are neatly cut and removed. The composite samples were cured by exposure to normal atmospheric conditions. The dimensions of different specimen were marked on the top surface of the composite by using a permanent marker pen. The fabricated composites were cut using a Jig saw machine to obtain the specimen of desired shape for mechanical testing as per the ASTM E10-18 standards for Brinell hardness test.

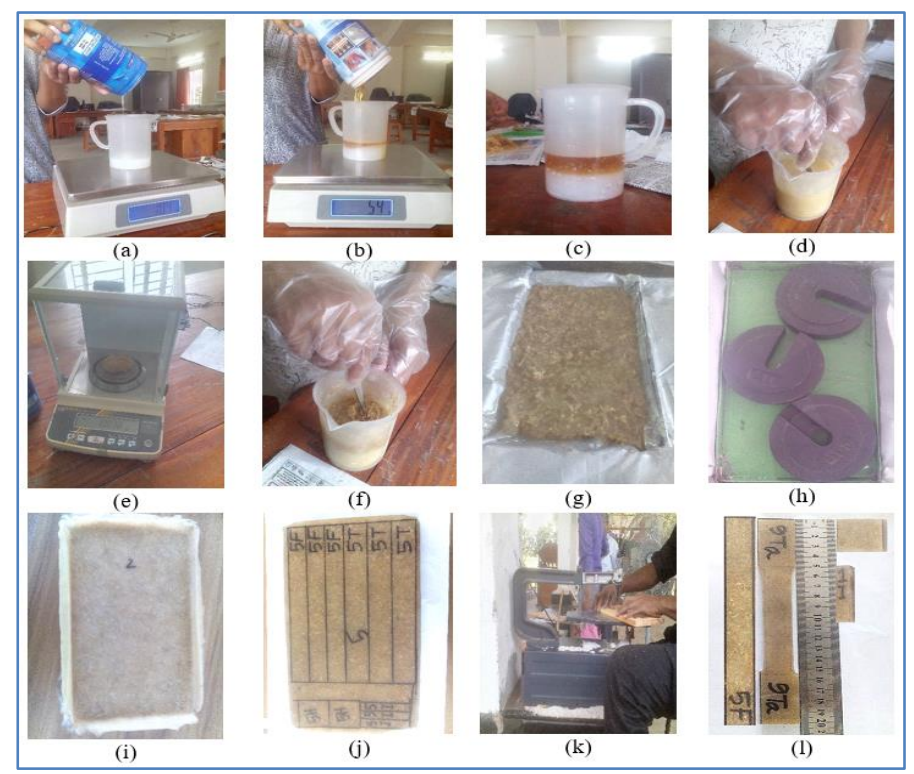

Fig-1: Complete sequential process for fabrication (a) Measuring mass of Epoxy resin (b) Measuring mass of Hardener (c) Taking appropriate proportion of Epoxy resin and Hardener (d) Mixing Epoxy and Hardener (e) Measuring mass of fibers (f) Mixing resin and fibers in appropriate proportion (g) Pouring of mixer into the mold (h) Applying pressure on mold (i) Curing by exposure to atmospheric condition (j) Marking on specimen (k) cutting by a Jig saw machine (l) Specimens for different tests.

\section{Taguchi Method}

Taguchi method is a combination of statistical and mathematical techniques. It is an efficient and powerful tool for the optimization of process parameters. The two major tools used in Taguchi method are Means and orthogonal arrays [22]. The experimental result analysis uses Means to aid in the determination of the best process or product design [23]. Maximization of mechanical property is the prime objective of this study. So, larger is better performance characteristics is considered. These characteristics can be calculated using the expression shown in equation (1).

$$
\eta(d B)=-10 \log _{10} \frac{1}{n} \sum_{i=1}^{n} \frac{1}{y_{i}^{2}}
$$

Where, $y_{i}$ is the $i^{\text {th }}$ value of the response variable.

An important step in design of experiments is the selection of control factors. Four control factors i.e., $\mathrm{Wt} \%$ ratio of resin \& hardener $(\mathrm{A}), \mathrm{Wt} \%$ of resin \& hardener in composite $(\mathrm{B}), \mathrm{Wt} \%$ ratio of sponge gourd
\& jute $(\mathrm{C})$, and $\mathrm{Wt} \%$ ratio of sponge gourd \& coir (D), each at three levels are considered in this study. The influence of four factors were studied using L9 $\left(3^{4}\right)$ orthogonal design, where 9 experiments are sufficient to optimize the parameters. Control factors and their levels are shown in table 1.

Table-1: Levels of the variables used in the experiment.

\begin{tabular}{|c|c|c|c|}
\hline Control factors & \multicolumn{3}{|c|}{ Levels } \\
\cline { 2 - 4 } & 1 & 2 & 3 \\
\hline Wt\% ratio of resin \& hardener, A & 1.50 & 1.25 & 1.00 \\
\hline Wt\% of resin \& hardener in composite, B & 91 & 88 & 85 \\
\hline Wt\% ratio of sponge gourd \& jute, C & 0.33 & 1.00 & 3.00 \\
\hline Wt\% ratio of sponge gourd \& coir, D & 0.33 & 1.00 & 3.00 \\
\hline
\end{tabular}

\section{RESULTS AND DISCUSSION}

Table 2 shows the L9 orthogonal array designed by using Taguchi method with Brinell hardness values of these natural composites. Experiment no. 7 gives the maximum Brinell hardness value (67.337), where $\mathrm{Wt} \%$ ratio of resin \& hardener: 
1:1, Wt\% of resin \& hardener in composite: $91 \%, \mathrm{Wt} \%$ ratio of sponge gourd \& jute, and $\mathrm{Wt} \%$ ratio of sponge gourd \& coir are 1.00, 91, 3.00 and 1.00 respectively. On the other hand, experiment no. 3 reveals the minimum hardness value $(39.010)$, where $\mathrm{Wt} \%$ ratio of resin \& hardener, $\mathrm{Wt} \%$ of resin \& hardener in composite, $\mathrm{Wt} \%$ ratio of sponge gourd \& jute, and $\mathrm{Wt} \%$ ratio of sponge gourd \& coir are 1.50, 85, 3.00 and 3.00 respectively. From table 2, anyone can choose the factors according to their need of Brinell hardness values of the natural composites.

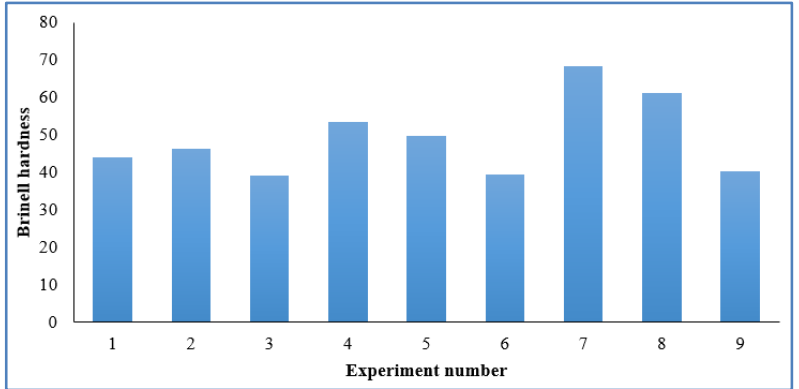

Fig-2: Brinell hardness vs. experiment number graph of the composite.

Figure 2 reveals the graph indicating Brinell hardness values corresponding to the experiment number. The graph shows, experiment number 7 gives the higher value of Brinell hardness. On the other hand, experiment number 3 gives the lower Brinell hardness value.

Table-2: Taguchi Experimental design of process parameters for Brinell hardness number of natural fiber reinforced composites using $\mathrm{L} 9$ orthogonal array

\begin{tabular}{|c|c|c|c|c|c|}
\hline $\begin{array}{c}\text { Experiment } \\
\text { No. }\end{array}$ & $\begin{array}{c}\text { Wt\% ratio } \\
\text { of resin \& } \\
\text { hardener }\end{array}$ & $\begin{array}{c}\text { Wt\% of resin } \\
\text { \& hardener in } \\
\text { composite }\end{array}$ & $\begin{array}{c}\text { Wt\% ratio of } \\
\text { sponge gourd \& } \\
\text { jute }\end{array}$ & $\begin{array}{c}\text { Wt\% ratio of } \\
\text { sponge gourd } \\
\text { \& coir }\end{array}$ & $\begin{array}{c}\text { Brinell } \\
\text { Hardness } \\
\text { (BH) }\end{array}$ \\
\hline 1 & 1.50 & 91 & 0.33 & 0.33 & 43.880 \\
\hline 2 & 1.50 & 88 & 1.00 & 1.00 & 46.250 \\
\hline 3 & 1.50 & 85 & 3.00 & 3.00 & 39.010 \\
\hline 4 & 1.25 & 91 & 1.00 & 3.00 & 53.330 \\
\hline 5 & 1.25 & 88 & 3.00 & 0.33 & 49.710 \\
\hline 6 & 1.25 & 85 & 0.33 & 1.00 & 39.310 \\
\hline 7 & 1.00 & 91 & 3.00 & 1.00 & 67.337 \\
\hline 8 & 1.00 & 88 & 0.33 & 3.00 & 61.279 \\
\hline 9 & 1.00 & 85 & 1.00 & 0.33 & 40.340 \\
\hline
\end{tabular}

\section{Taguchi Analysis}

The response table for means is shown in table 3 for Brinell hardness of the natural composites. From table 3 and figure 3 , it is seen that variations are small for the factor $\mathrm{Wt} \%$ ratio of sponge gourd \& jute, very low response in case of 1.00 level value. High variation comes from $\mathrm{Wt} \%$ of resin $\&$ hardener in composite. So at a first glance, it may be predicted that $\mathrm{Wt} \%$ of resin $\&$ hardener would be the main cause of improvement of Brinell hardness. With increase of $\mathrm{Wt} \%$ of resin \& hardener, the value of Brinell hardness is almost linearly improved. High response from $91 \mathrm{Wt} \%$ of resin $\&$ hardener in the natural composite that was somewhat desired for Brinell hardness. Very shocking results are obtained in case of $85 \mathrm{Wt} \%$ of resin \& hardener. $\mathrm{Wt} \%$ ratio of resin $\&$ hardener is second favorable option for the improvement of Brinell hardness. Here, the values of Brinell hardness are linearly decreased with increasing values of $\mathrm{Wt} \%$ ratio of resin \& hardener. But, it should be kept in mind that, 1.50 ratio should be avoided. As the ratio decreases, that is, relative reduction of resin compared to hardener in the composite, much better results can be obtained. But, the result is higher incremental for the ratio of 1 , further decrement provides little improvement. $\mathrm{Wt} \%$ ratio of sponge gourd \& coir is another option which affects the hardness of the composites. But, it should be kept in mind that 0.33 ratio should be avoided. As the ratio increase, that is, relative reduction of coir fiber to the sponge gourd fiber, much better results can be obtained. But the result is higher incremental for the ratio of 1.00 .

Table-3: Response table for means of Brinell hardness at various levels of input parameters

\begin{tabular}{|c|c|c|c|c|}
\hline Level & $\begin{array}{c}\text { Wt\% ratio } \\
\text { of resin \& } \\
\text { hardener }(\mathbf{A})\end{array}$ & $\begin{array}{c}\text { Wt\% of } \\
\text { resin \& } \\
\text { hardener }(\mathbf{B})\end{array}$ & $\begin{array}{c}\text { Wt\% ratio } \\
\text { of sponge } \\
\text { g. (gourd) \& jute (C) }\end{array}$ & $\begin{array}{c}\text { Wt\% ratio } \\
\text { of sponge } \\
\text { g. \& coir (D) }\end{array}$ \\
\hline 1 & $\mathbf{5 6 . 6 5}$ & 39.55 & 48.16 & 44.64 \\
\hline 2 & 47.45 & 52.41 & 46.64 & $\mathbf{5 1 . 3 0}$ \\
\hline 3 & 43.05 & $\mathbf{5 5 . 1 8}$ & $\mathbf{5 2 . 3 5}$ & 51.21 \\
\hline Delta & 13.61 & 15.63 & 5.71 & 6.66 \\
\hline Rank & 2 & 1 & 4 & 3 \\
\hline
\end{tabular}




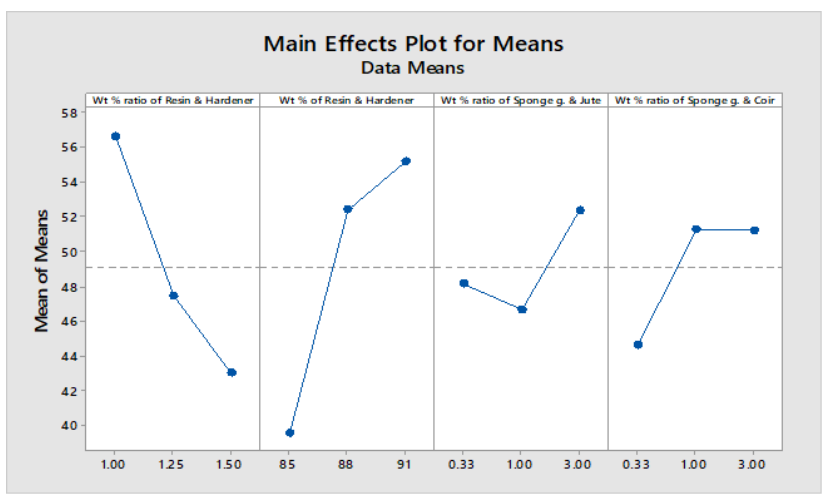

Fig-3: Main effect plots for means values of Brinell hardness

\section{Confirmation Experiment}

Maximum Brinell hardness is found in $\mathrm{A} 1$

(Wt\% ratio of resin \& hardener: $1: 1), \mathrm{B} 3(\mathrm{Wt} \%$ of resin \& hardener in composite: $91 \%$ ), $\mathrm{C} 3$ (Wt\% ratio of sponge gourd \& jute: $3: 1$ ), and $\mathrm{D} 2$ ( $\mathrm{Wt} \%$ ratio of sponge gourd \& coir: 1:1) conditions. The confirmation experiments were carried out in three different samples with the control factors set at their optimal levels. The predicted maximum Brinell hardness is given by equation:

Brinell hardness (Predicted $)=\mathrm{A}_{1}+\mathrm{B}_{3}+\mathrm{C}_{3}+\mathrm{D}_{2}-3 \mathrm{Y}$

Where $A_{i}, B_{i}, C_{i}$ and $D_{i}$ are the average mean values of Brinell hardness at their $i^{\text {th }}$ levels respectively, and $\mathrm{Y}$ is the overall mean. The predicted and experimental values of Brinell hardness are 68.34 and 71.62 respectively where the percentage of error is only $4.58 \%$.

\section{Interaction Plots Results}

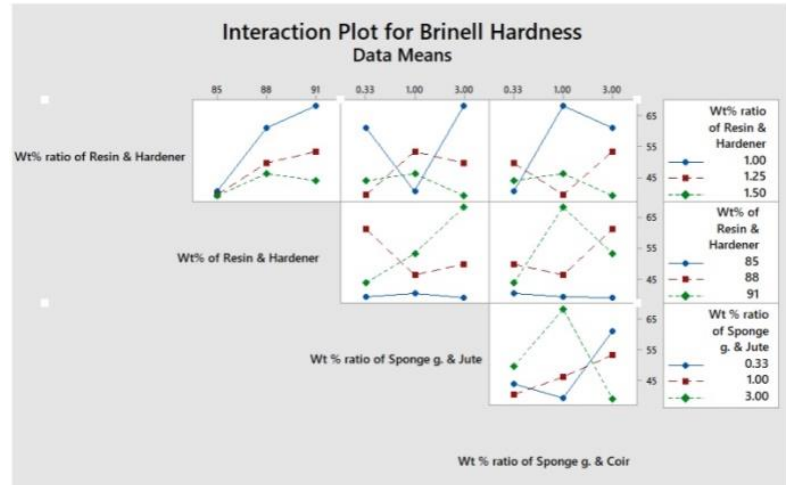

Fig-4: Interaction Plots for Brinell hardness

Figure 4 shows that, the combinational effect of two factors, like $\mathrm{Wt} \%$ of resin \& hardener along with $\mathrm{Wt} \%$ ratio of resin \& hardener provide improved Brinell hardness value for $\mathrm{Wt} \%$ ratio of resin \& hardener of level value 1.00 with increasing level value of 91 for $\mathrm{Wt} \%$ of resin \& hardener. It indicates that more improvement is possible with $\mathrm{Wt} \%$ of resin \& hardener higher than 91 when $\mathrm{Wt} \%$ ratio of resin \& hardener of value 1.00 will be considered. Level value of 1.50 for $\mathrm{Wt} \%$ ratio of resin \& hardener provides the worst response when it interacts with various level values of $\mathrm{Wt} \%$ of resin \& hardener. So this combination should be avoided. Improvement slope is lesser when $\mathrm{Wt} \%$ ratio of resin \& hardener of value 1.25 is considered with level values of $\mathrm{Wt} \%$ of resin \& hardener than $\mathrm{Wt} \%$ ratio of resin \& hardener of value 1.00. If it is desired to improve response value of Brinell hardness in very large scale considering interaction between two factors, $\mathrm{Wt} \%$ of resin \& hardener along with $\mathrm{Wt} \%$ ratio of resin $\&$ hardener, level value of 1.00 for $\mathrm{Wt} \%$ ratio of resin $\&$ hardener is highly recommended to remain fixed with increasing level value for $\mathrm{Wt} \%$ of resin \& hardener.

When, $\mathrm{Wt} \%$ ratio of resin \& hardener interacts with $\mathrm{Wt} \%$ ratio of sponge gourd \& jute, level value of 1.00 for $\mathrm{Wt} \%$ ratio of resin \& hardener is sensitive to specific point. It provides the worst response when level value for $\mathrm{Wt} \%$ ratio of sponge gourd \& jute is 1.00 . But level value of 3.00 for $\mathrm{Wt} \%$ ratio of sponge gourd \& jute shows best improved response and response for level value of 0.33 for $\mathrm{Wt} \%$ ratio of sponge gourd \& jute is not as bad as for level value of 1.00 of same factor. Other two level values for $\mathrm{Wt} \%$ ratio of resin \& hardener, do not support much improvement scopes when they interact with various level values of $\mathrm{Wt} \%$ ratio of sponge gourd $\&$ jute.

In case of interaction between two factors, $\mathrm{Wt} \%$ ratio of resin \& hardener and $\mathrm{Wt} \%$ ratio of sponge gourd \& coir, also level value of 1.00 for $\mathrm{Wt} \%$ ratio of resin \& hardener provides larger improvement scope than other values. Specifically level value of 1.00 for $\mathrm{Wt} \%$ ratio of sponge gourd \& coir has the largest response change with previous one, but level value of 3.00 for $\mathrm{Wt} \%$ ratio of sponge gourd \& coir doesn't indicate a huge change of response compared to change between level values 0.33 and 1.00 of same factor. The response may be checked for some values higher than 3.00 for $\mathrm{Wt} \%$ ratio of sponge gourd \& coir to make a better decision.

\section{CONCLUSION}

The following conclusions are drawn regarding the above discussion:

- Hardness behavior of these composites were investigated where combinations of control factors in each sample was designed by Taguchi method.

- It was explored from the Taguchi analysis that the combination of $\mathrm{Wt} \%$ ratio of resin \& hardener: $1: 1$, $\mathrm{Wt} \%$ of resin \& hardener in composite: $91 \%$, Wt $\%$ ratio of sponge gourd \& jute: $3: 1$, and $\mathrm{Wt} \%$ ratio of sponge gourd \& coir: $1: 1$ conditions was the optimal setting for obtaining maximum Brinell hardness.

- Confirmation experiments were carried out with the optimal settings on three different samples. The average hardness was 71.62 which were in good 
agreement with the predicted responses and have a little deviation of $4.58 \%$.

- The interaction effects of various combinations between two control factors over hardness behavior are represented graphically by interaction plots.

\section{ACKNOWLEDGEMENT}

The study was a part of first author's M. Sc. thesis work. Authors would like to thank Md. Abu Sufian, Md. Ajgor Ali, Assistant Technical Officer, Md. Imran Hossain, Lab Assistant Bangladesh Army University of Science and Technology for their cordial cooperation during this research.

\section{REFERENCES}

1. Kabir, M. M., Wang, H., Lau, K. T., \& Cardona, F. (2012). Chemical treatments on plant-based natural fibre reinforced polymer composites: An overview. Composites Part B: Engineering, 43(7), 2883-2892.

2. O'donnell, A., Dweib, M. A., \& Wool, R. P. (2004). Natural fiber composites with plant oilbased resin. Composites science and technology, 64(9), 1135-1145.

3. Bassett, S. (1998). Composites for Infrastructure: A Guide for Civil Engineers. USA, Ray Publ.

4. Cheung, H. Y., Ho, M. P., Lau, K. T., Cardona, F., \& Hui, D. (2009). Natural fibre-reinforced composites for bioengineering and environmental engineering applications. Composites Part B: Engineering, 40(7), 655-663.

5. Mohammed, L., Ansari, M. N., Pua, G., Jawaid, M., \& Islam, M. S. (2015). A review on natural fiber reinforced polymer composite and its applications. International Journal of Polymer Science, 2015.

6. Ticoalu, A., Aravinthan, T., \& Cardona, F. (2010). A review of current development in natural fiber composites for structural and infrastructure applications. In Proceedings of the southern region engineering conference (SREC 2010) (pp. 113117). Engineers Australia.

7. Ayrilmis, N., Jarusombuti, S., Fueangvivat, V., Bauchongkol, P., \& White, R. H. (2011). Coir fiber reinforced polypropylene composite panel for automotive interior applications. Fibers and Polymers, 12(7), 919.

8. Bhagat, V. K., Prasad, A. K., \& Srivatava, A. K. L. (2017). Physical and mechanical performance of luffa-coir fiber reinforced epoxy resin based hybrid composites. International Journal of Civil Engineering and Technology, 8 (6), 722, 731.

9. Khan, M. N., Roy, J. K., Akter, N., Zaman, H. U., Islam, T., \& Khan, R. A. (2012). Production and properties of short jute and short e-glass fiber reinforced polypropylene-based composites. Open journal of composite materials, 2(02), 40.

10. Siddika, S., Mansura, F., \& Hasan, M. (2013). Physico-mechanical properties of jute-coir fiber reinforced hybrid polypropylene composites. Engineering and Technology, 73, 1145-1149.

11. Sailesh, A., \& Shanjeevi, C. (2014). Predicting the best hardness of Banana-Bamboo-Glass fiber reinforced Natural fiber composites using Taguchi method. International Journal of Engineering Development and Research, ISSN, 2, 89-92.

12. Ichetaonye, S. I., Madufor, I. C., Yibowei, M. E., \& Ichetaonye, D. N. (2015). Physico-Mechanical Properties of Luffa aegyptiaca Fiber Reinforced Polymer Matrix Composite. Open journal of composite materials, 5(04), 110.

13. Sreeramulu, D., \& Ramesh, N. (2018). Synthesis, characterization, and properties of epoxy filled Luffa cylindrica reinforced composites. Materials Today: Proceedings, 5(2), 6518-6524.

14. Gafur, M. A., \& Mina, M. F. (2018). Preparation and characterization of raw and chemically modified sponge-gourd fiber reinforced polylactic acid biocomposites. Materials Sciences and Applications, 9(02), 281.

15. Tanobe, V. O., Flores-Sahagun, T. H., Amico, S. C., Muniz, G. I., \& Satyanarayana, K. G. (2014). Sponge gourd (Luffa cylindrica) reinforced polyester composites: preparation and properties. Defence Science Journal, 64(3), 273-280.

16. Escocio, V. A., Visconte, L. L., Cavalcante, A. D. P., Furtado, A. M. S., \& Pacheco, E. B. (2015, May). Study of mechanical and morphological properties of bio-based polyethylene (HDPE) and sponge-gourds (Luffa-cylindrica) agroresidue composites. In AIP Conference Proceedings (Vol. 1664, No. 1, p. 060012). AIP Publishing.

17. Boynard, C. A., Monteiro, S. N., \& d'Almeida, J. R. M. (2003). Aspects of alkali treatment of sponge gourd (Luffa cylindrica) fibers on the flexural properties of polyester matrix composites. Journal of Applied Polymer Science, 87(12), 1927-1932.

18. Pickering, K. (Ed.). (2008). Properties and performance of natural-fibre composites. Elsevier.

19. Hill, C. A. S., \& Abdul Khalil, H. P. S. (2000). Effect of fiber treatments on mechanical properties of coir or oil palm fiber reinforced polyester composites. Journal of Applied Polymer Science, 78(9), 1685-1697.

20. Watson, M. (1990). Jute and flax mills in Dundee (pp. 53-57). Tayport, Fife: Hutton Press.

21. Rafiquzzaman, M., Rahman, M. H., Sayeed, M. A., \& Ali, M. N. (2016). Evaluation of Mechanical Behavior of Jute Fibre-Aluminum Powder Reinforced Hybrid Polymer Composites. Int. J. Mech. Eng. Autom, 3(5), 202-207.

22. Ghani, J. A., Choudhury, I. A., \& Hassan, H. H. (2004). Application of Taguchi method in the optimization of end milling parameters. Journal of materials processing technology, 145(1), 84-92.

23. Bement, T. R. (1989). Taguchi techniques for quality engineering. 